http://spilplus.journals.ac.za/

134

\title{
DIE INHOUD EN PLEK VAN NORME IN DIE VERTAALPRAKTYK, VERTAALKUNDE, VERTAALKRITIEK EN DIE VERTAALWETENSKAP
}

\author{
Mnr.G.Kroes, Dept. Afrikaans en Nederlands, Universiteit Stellenbosch
}

1. Inleiding

Wanneer iemand kommunikeer, word sy boodskap altyd met 'n doel op sy hoorder(s) of Jeser(s) gerig. Hy wil byvoorbeeld informasie oordra, sy lesers van 'n bepaalde standpunt oortuig, hulle ben̈nvloed, hulle jets leer of hulle sin vir literêre skoonheid bevredig. By vertaling, wat 'n vorm van kommunikasie is, het die vertaler ook altyd 'n doel met sy vertaling, al word dit dikwels aan hom opgedra. "Translating" sê Toury (1985: 19) "as a teleological activity par excellence is to a large extent conditioned by the goals it is designed to serve, and these goals are set in, and by, the prospective receptor systems(s). Consequently, translators operate first and foremost in the interest of the culture into which they are translating, and not in the interest of the source text, let alone the source culture."

Dikwels kies die vertaler dieselfde doelstellings as die bronteksskrywer, maar omdat hy nie in dieseifde kommunikasiesituasie staan as die bronteksskrywer nie en hom op ander lesers rig, kan die vertaler besluit om sy doelstellings by sy bepaalde omstandighede aan te pas.

Om te beoordeel of 'n vertaler ' $n$ goeje vertaling gelewer het, is dit nodig om vas te stel wat sy doelstellings was en in hoeverre hy daardie doelstellings verwesenlik het. Om te bepaal of hy sy doelstellings verwesenlik het, moet die beoordelaar vasstel wat die norme is waaraan soortgelyke tekste in die doeltaal normaalweg voldoen om daardie selfde doelstellings te verwesenlik, en in watter mate die vertaling aan bogenoemde norme voldoen.

Wat die vertaler, die Vertaalkunde, en die Vertaalkritiek dus van die Vertaalwetenskap in verband met vertaalnorme verlang, is om antwoorde op die volgende vrae te vind:

(i) Wat is die inhoud van vertaalnorme? 
http://spilplus.journals.ac.za/

135

(ii) Hoe ontstaan vertaalnorme?

(iii) Wat is die plek van vertaalnorme in die vertaalpraktyk, die Vertaalkunde en in die Vertaalkritiek?

(iv) Hoe word norme by vertaling toegepas?

In hierdie referaat wil ek bogenoemde vrae beantwoord op grond van Gideon Toury se bydrae tot die Vertaalwetenskap.

\section{Norme in die vertaalpraktyk}

In die vertaalpraktyk in Suid-Afrika neem norme die vorm aan van vaagomlynde, heel algemene, ongeskrewe riglyne. In vertaalkantore, waar hoofsaaklik informatiewe tekste vertaal word, kry 'n beginner sy opdrag om 'n teks te vertaal van 'n senior vertaler, met die veronderstelling dat hy sal weet hoe om sy opdrag uit te voer. ' $n$ Senior vertaler sien gewoonlik 'n beginner se werk na en dui die "foute" aan of doen ander vertaalmoontlikhede aan die hand. Daar word selde vertaalkundige motiverings vir hierdie "korreksies" verstrek. Die beginner moet self afleiop grond van watter norme die veranderings sy vertaling "verbeter".

Indien 'n vertaler nie saam met ander vertalers werk nie, kry hy sy opdragte van sy werkgewer wat nie self ' $n$ vertaler is nie en gewoonlik, soos die senior vertaler, ook aanvaar dat die vertaler weet wat van hom verwag word. Soms dink sulke opdraggewers dat ' $\mathrm{n}$ vertaling swak is indien daar ooreenkomste in vorm tussen die vertaling en die bronteks voorkom. So 'n vertaler kry dan die opdrag om nie so letterlik te vertaal nie. In ander gevalle word kritiek op die vertaling uitgespreek as dit nie dieselfde ruimte beslaan as die bronteks nie, of as daar bepaalde brontekswoorde "wegvertaal" is of nuwe inhoude bygevoeg is. Sulke kritiek word selde taalkundig gemotiveer en die opdraggewer kan ook nie duidelik sê wat hy van sy vertaler verwag nie.

Die gebruiklikste doelstelling by bogenoemde vertalers en opdraggewers is dat die vertaling die informasie van die bronteks so akkuraat as moontlik moet oorgedra. Die norme waaraan sulke vertalings gewoonlik moet voldoen, is dat hulle sin vir sin die betekenis van die bronteks in 'n natuurlike, idiomatiese doeltaal moet oordra. 
http://spilplus.journals.ac.za/

Alhoewel die norme van akkurate betekenisoordrag en idiomatiese taalgebruik heeltemal geldige en algemeen erkende norme is, laat dit die vertaler steeds met talle onsekerhede. Mag hy byvoorbeeld verbeteringe in die sy vertaling aanbring waar die bronteks onduidelik, dubbelsinnig, inkonsekwent of onelegant geformuleer is? Watter soort inhoude mag hy byvoeg, weglaat of verander, in watter tipe tekste en in watter omstandighede? Mag hy lang sinne in korter sinne verdeel, die volgorde van sinsdele verander, die opskrifte en indeling van die teks verander? In watter omstandighede is so iets wel toelaatbaar en in watter omstandighede nie?

In die kantoor waar reklamekopie vertaal word, is die vraag of dieselfde norme wat vir informatiewe tekste geld ook op reklametekste van toepassing is? Het die reklamevertaler groter vryheid wat die vertaling van vorm en inhoud betref? In watter omstandighede wel en in watter omstandighede nie?

Laastens is daar die onsekerheid waarmee sommige vertalers van literêre tekste te werk gaan en die "sekerheid" waarmee ander vertaal. Omdat daas vir die vertaling van hierdie soort tekste ook geen duidelik omskrewe norme bestaan nie, het sommige vertalers hulle eie stel norme wat hulle minder of meer sistematies toepas, terwyl ander vertalers hoofsaaklik intuïtief te werk gaan, Ook hier duik die vraag telkens op: Volgens watter norme mag 'n vertaler wel of nie linguisties, tekstueel, stilisties en pragmaties van die bronteks afwyk, in watter mate, en in watter omstandighede?

\section{Norme in die Vertaalkritiek}

Van die Vertaalkritiek word objektiewe uitsprake oor die gehalte van vertaalde tekste verwag. Hieroor sê Van den Broeck en Lefevere (1984: 159): "Tot voor (heel) kort werd eenvoudig vrijwel niets aan vertaalkritiek gedaan. Men recenseerde gewoon een vertaald literair werk alsof het om een brontekst ging. Een enkele keer sprak men ook met een paar woorden over de kwaliteit van de vertaling zelf, maar doorgaans op uiterst subjectieve basis ... ." Na my mening kan geen sinvolle kritiek op 'n vertaling uitspreek word alvorens die kritikus nie vasgestel het nie:

a) met watter doel die vertaler die teks vertaal het, 
http://spilplus.journals.ac.za/

b) volgens watter norme die vertaler te werk gegaan het, en

c) op watter lesers die vertaler hom waarskynlik gerig het.

Op grond van hierdie kriteria kan die kritikus nagaan;

a) of die vertaler hom deurgaans op sy doel afgestuur het,

b) of hy so ver moontlik konsekwent was in die toepassing van die relevante norme en

c) of hy hom deurgaans op sy waarskynlike lesers ingestel het.

Afwyking van hierdie kriteria moet gemotiveerd wees. Om hierdie rede lyk dit vir iny wenslik dat 'n vertaler van 'n literêre werk in 'n voorwoord kortliks sy vertaalbeleid vir die betrokke werk stel. Indien hy dit nie gedoen het nie, is dit die resensent se taak om uit 'n vergelyking van die vertaling met die bronteks, na te gaan wat die vertaler se beleid waarskynlik was, in watter mate hy hom aan die relevante norme onderwerp het en gevolglik in sy doel geslaag het.

\section{Norme in die Vertaalkunde}

Die Vertaalkunde is die dissipline wat hom met die praktyk gerigte studie van konkrete vertaajopdragte besig hou, soos byvoorbeeld die vertaling van konkrete tekste uit 'n brontaal in 'n doeltaal. Dit is veral didakties gerig en hou hom besig met die onderrig van vertaalvaardighede en -metodes.

In die Vertaalkunde moet die insigte wat objektief en sistematies deur die Vertaalwetenskap verwerf is, getoets word aan die vraag hoe die beste vertalings gemaak kan word. In die praktyk is dit van belang dat die vertaler die doelstellings wat hy kies so goed as moontlik verwesenlik. Om hulle te kan verwesenlik moet moet hy deurgaans bepaalde norme in aanmerking neem. Van den Broeck en Lefevere (1984: 178) stel dit soos volg: "Voor elk vertaler is de doelkeuze immers essentieel. Het praktische vertalen is onmogelijk buiten bepaalde normen. Hoe beter verantwoord de vertaler zijn normen kiest, des te waardevoller resultaten hij zal kunnen bereiken. De opleiding moet er dus op gericht zijn de toekomstige vertaler niet alleen sationeel inzich in de technische problematiek maar ook een feilloos gevoel voor normen bij te brengen: zij moet hem of haar normenbewust 
http://spilplus.journals.ac.za/

138

maken. De praktische oefeningen in het vertalen en de kritische bespreking van bestaande of zelf gemaakte vertalingen zouden precies daarop gericht moeten zijn."

Die norme wat op die oomblik vir die Vertaalkunde beskikbaar is, en waaruit die vertaler ' $n$ bepaalde keuse moet maak, is heel algemene en vaag omlynde maatstawwe, soos byvoorbeeld: 'n vertaling moet die informasie van die bronteks getrou oordra, 'n vertaling moet dinamies ekwivalent aan die bronteks wees, 'n vertaling moet formeel ekwivalent aan die bronteks wees, 'n vertaling moet min of meer dieselfde kommunikasielas vir die doeltaallesers hê as wat die bronteks vir die brontaallesers het, en 'n vertaling moet dieselfde trefkrag as die bronteks hê.

Die Vertaalkunde soek dus bulp by die Vertaalwetenskap om inligting te verkry oor die norme waraan vertalers hulle by die vertaling van bepaalde tipe tekste in bepaalde kommunikasiesituasies normaalweg onderwerp om bepaalde doelstellings te verwesenlik.

\section{Norme in die Vertaalwetenskap}

Die Vertaalwetenskap is die dissipline wat hom besig hou met die ondersoek van vertalings, van die vertaalprosesse waaruit sulke tekste ontstaan het en die manier waarop hierdie tekste in die doelkultuur fuksioneer. Omdat Gideon Toury van die belangrikste werk oor die rol van norme by vertaling gepubliseer het, gebruik ek gedeeltes daarvan om aan te toon watter insigte die vertaalwetenskap aan die vertaalprofessie bied. Alhoewel in die jongste tyd ook belangrike werk oor die rol van relevansie as norm by vertaling gepubliseer is, is dit met opset nie hier bespreek nie, omdat die teorie van relevansie deur Sinclair (1992) en Winckler (1992) in hierdie bundel referate aan die orde gestel word.

\subsection{Die begrip "norm"}

Volgens Toury (1980: 51) is vertaling, soos verskeie ander vorme van gedrag, onderworpe aan beperkings wat in hulle graad van voorskriftelikbeid verskil. 
Hierdie beperkings kan beskryf word as 'n skaal tussen twee uiterstes: aan die een kant is daar objektiewe, redelik absolute reëls (op sommige gedragsterreine selfs vaste, geformuleerde wette) en aan die ander kant volkome subjektiewe idiosinkrasieë. Die middelgebied tussen hierdie twee pole word ingeneem deur intersubjektiewe faktore wat gewoonlik as "norme" bekend staan. Hierdie tussengebied kan as 'n gegradueerde kontinuum beskryf word en die norme kan op enige plek daarop voorkom.

\subsection{Die ontstaan van norme}

Volgens sosioloè is norme algemene waardes of idees oor wat binne 'n sekere gemeenskap reg of verkeerd, gepas of ongepas is en in spesifieke instruksies vir optrede omgesit is. Hierdie waardes word deur die betrokke gemeenskap gedeel en die instruksies is gepas vir spesifieke situasies. Om as norme te kwalifiseer mag hierdie instruksies nie as wette geformuleer wees nie. Norme kan beskou word as kriteria waarvolgens optrede, deur die groep of deur sy individuele lede, beoordeel word. Norme bestaan in situasies wat variasie van optrede toelaat. Sulke variasie is of betekenisloos, d.w.s. 'n geval van vrye variasie, of patroonmatig, d.w.s. gerig op en beheer deur norme, synde 'n geval van "gebonde variasie". In soverre 'n norm werklik aktief en doeltreffend is, kan reëlmatigheid van optrede in herhaalde situasies van dieselfde tipe onderskei word. By die ondersoek van optrede, is sulke reëlmatighede die belangrikste getuienis vir die bestaan en funksionering van norme. (Toury 1980: 51)

Sinkronies is die grenslyne tussen hierdie drie tipes beperkings, naamlik wette, norme en idiosinkrasieë, yaag. Diakronies kan elke tipe beperking na die aangrensende domein beweeg op grond van aanvaarding of verwerping van bepaalde norme. In die Klassieke tyd was dit byvoorbeeld normaal om verhale in ritmiese, rymende verse te vertel; in latere periodes is die prosavorm hiervoor verkies. 
http://spilplus.journals.ac.za/

5.3 Norme by die vertaling van literêre tekste

Literêre vertaling is die produk van 'n komplekse prosedure waarby onvermydelik twee tale en twee literêre tradisies, d.w.s. twee stelle normsisteme betrokke is. Volgens Toury (1980: 53) bestaan die "waarde" (sien par. 2.4.2) agter die norme van literêre vertaling uit twee hoofelemente:

(a) die doelteks moet 'n literêre werk wees wat dje moeite werd is binne die literêre polisisteern van die doeltaal;

(b) die doelteks moet ' $n$ vertaling wees, d.w.s. die representasie in die doeltaal van ' $n$ ander, vooraf bestaande teks in ' $n$ ander taal, die brontaal, en hierdie bronteks is afkomstig iit 'n ander literêre polisisteem, dié van die brontaal en beklee ' $n$ sekere posisie daarin.

Hierdie "waarde" bevat gevolglik vereistes afkomstig uit twee wesentlik verskillende bronne wat dikwels onversoenbaar, of ook lynreg opponerend kan wees. Dit is die hoofrede vir die besondere kompleksiteit van die situasie wat hom ontvou wanneer 'n mens die terrein van vertaalnorme betree.

Norme tree binne elke fase van die vertaalproses op en is op elke vlak van sy produk werksaam. Toury (1980: 53) onderskei eers tussen twee groter groepe vertaalnorme, naamilk preliminêre en operasionele norme en voeg dan 'n derde tipe, die inisiële norm by.

\subsubsection{Preliminêre norme}

Prelininêre norme het te doen met twee hoofstelle oorwegings: dié wat betrekking op die spesifieke vertaalbeleid en dié wat betrekking het op die "direktheid" van vertaling. As oorwegings by vertaalbeleid noem Toury (1890: 53) faktore wat die keuse van die bronteks betref, of ten minste die outeur, genre, literêre skool, doelliteratuur ens. Oorwegings van die direktheid van vertaling het te make met die mate waarin toegelaat word dat ook uit ander tale as die brontaal vertaal word. Word 'n tweedehandse vertaling d.w.s. 'n vertaling uit 'n bestaande vertaling, toegelaat? Uit watter (primere) bronliterature of literêre sisteme/periodes word 


\section{http://spilplus.journals.ac.za/}

141

die vertaling toegelaat/verbied/geduld/verkies. Watter intermediere tale word toegelaat/verbied/geduld/verkies? Is daar 'n neiging/verpligting om in 'n subtitel te meld dat die vertaling 'n tweedehandse vertaling is, of word hierdie feit geïgnoreer?

\subsubsection{Operasionele norme}

Operasionele norme lei die vertaler by sy besluite tydens die vertaalproses. Hulle bestaan uit twee subtipes, naamlik matriksnorme en tekstuele norme.

\subsubsection{Matriksnorme}

Matriksnorme het betrekking op die matriks van die teks, d.w.S. op die manier waarop die linguistiese materiaal (veral die groter eenhede) in die teks versprei word. Matriksnorme bepaal (of het ten minste 'n belangrike uitwerking) op die werklike bestaan van doeltaalmateriaal wat bedoel is as 'n plaasvervanger vir die korresponderende brontaalmateriaal (en gevolglik die graad van volledigheid van die vertaling. Dit bepaal die plasing van die doeltaalmateriaal binne die teks (d.w.s. die vorm van die werklike verspreiding daarvan) en die tekstuele segmentering beide bo sinsvlak sowel as op die suiwer (jiterêre) teksvlak. Hulle bepaal ook die mate warin openlik in die vertaalde werk self verwys word na sulke weglatings, toevoegings, veranderings in plasing, en manipulasie van segmente, aan die hand van verklarings soos verkort, verwerk en so meer. Die grense tussen hierdie matriksverskynsels is nie duidelik afgebaken nie. Weglating op groot skaal lewer ook dikwels veranderings in segmentering op; 'n verandering in plasing kan ook beskryf word as 'n weglating (op een plek) plus 'n toevoeging (op 'n ander plek) en so voorts. 


\section{http://spilplus.journals.ac.za/}

\subsubsection{Tekstuele norme}

Tekstuele norme het betrekking op die werklike verbale formulering van die teks. Tekstuele norme bepaal die eintlike keuse van doeitaalmateriaal (eenhede en patrone) - om die oorspronklike tekstuele en linguistiese materiaal te vervang, of (omdat ons aanvaar dat die blote konsep van vertaling in sy moderne betekenis een of ander elwivalensiepostulaat impliseer) om as vertaalekwivalente daarvoor te dien. Tekstuele norme kan of suiwer linguisties (insluitend algemene stilistiese norme) wees of literêr (waardeur byvoorbeeld bepaal word wat gepas is vir letterkunde in die algemeen, vir 'n vertaalde werk, vir 'n sekere genre/literêre bron/periode, vir 'n sekere literêre tegniek en so meer.

\subsubsection{Die inisiële norm}

Die inisiële norm is ' $n$ nuttige middel om te verwys na die vertaler se basiese keuse tussen twee polêre moontlikhede afgelei uit die twee belangrike komponente van die "waarde" in literêre vertaling wat in par.5.3 bespreek is: hy onderwerp hom $6 \mathrm{f}$ aan die oorspronklike teks met sy tekstuele verhoudings en die norme wat daarin uitgedruk is, of aan die heersende linguistiese en literêre norme van die doeltaal en die doeltaal-polisisteem, of 'n sekere gedeelte daarvan.

Die term "inisiële norm" moet hoofsaaklik algerneen opgevat word, d.w.s. volgens sy logiese prioriteit teenoor die ander, meer spesifieke norme. Dit tree op as 'n soort "definiërende instruksie" wat die paradigma van keuses bepaal. Die inisjële norm hoef nie kronologies ooreen te stem met die vertaalhandelinge en -besluite nie. Dit bepaal natuurlik vooraf die globale benadering tot 'n vertaling, maar die inisiële norm kan weer opduik - en dit gebeur gewoonlik - ook in die later stadia van die vertaalproses. Dit gebeur op 'n manier wat volledig of gedeeltelik in ooreenstemming is met die vooraf bepaalde oorhoofse gerigtheid van die vertaling; weer vir die hele teks, maar ook vir sy dele, of selfs klein eenhede en nietige besonderhede. 
http://spilplus.journals.ac.za/

143

\subsubsection{Interaksie tussen vertaalnorme}

Indien die vertaler bronteksgerigtheid as sy oorhoofse strategie kies, of hierdie benadering kies vir sekere gedeeltes of selfs slegs vir enkele besonderhede, neig die vertaling om die norme van die oorspronklike werk te gehoorsaam, en ook via die bronteksnorme, die norme van die brontaal en/of die norme van die hele brontaalliterêre polisisteem. Hierdie brosteksgerigte vertaling het Even-Zohar (1971: 47; 1975: 43) "adequate translation" genoem. Hierdie benadering kan natuurlik beteken dat die vertaling onversoenbaar is met die linguistiese en/of literêre norme van die doeltaal. Natuurlik kan sekere verskuiwings weg van die bronteks in ' $n$ adekwate vertaling voorkom - trouens, dit gebeur dikwels - maar hierdie verskuiwings kan beskou word as objektief en onontbeerlik, d.w.s. reëlgebonde, weens die inherente sisterniese verskille tussen die twee tale, en - in 'n mindere mate - tussen die twee betrokke letterkundes. Daarom versteur sulke verskuiwings nie die adekwaatheid van 'n vertaling wat op hierdie manier gedoen is nie.

Indien, aan die ander kant, die vertaler doeltaalgerigtheid as sy oorhoofse strategíe kies, word die operasionele linguistiese en literère norme van die doeltaalsisteem in werking gestel. Terwyl die toepassing van bronteksnorme die adekwaatheid van 'n vertaling bepaal, bepaal die toepassing van doelteksnorme sy aanvaarbaarheid binne die linguistiese en/of literêre polisisteem van die doeltaal, asook sy presiese plek daarin.

Volgens Toury (1980: 55) is dit redelik om te aarvaar dat die besluit wat geneem word gewoonlik een of ander kombinasie van (of kompromie tussen) hierdie twee uiterstes sal wees. Hy voeg by: "In my opinion, this is one of the best interpretations of the common argument that translation, especially literary translation, always involves an encounter, if not a confrontation, between two sets of norms, for it opens the door to exact scrutiny and description of this encounter or confrontation." (Toury, 1980: 55)

Toury (1980: 56) kom tot die belangrike gevolgtrekking dat, wanneer die vertaler die bronteksgerigte benadering kjes, die vertaling hoegenaamd nie in die doeltaal gemaak word nie, maar in 'n modeltaal wat op sy beste 'n deel van die doeltaal uitmaak en op sy slegste 'n kunsmatige, nie-bestaande taal is, en dat die vertaling nie aan die doeltaal- literêre polisisteem aangebied word nie, maar daarop 
http://spilplus.journals.ac.za/

144

afgedwing word. Wanneer aan die ander kant die doelteksgerigte benadering gekies word, bied die vertaler hoegenaand nie die oorspronklike werk aan, aan die doeltaalliteratuur nie, maar' $n$ versie daarvan, gesny volgens die mate van 'n vooraf bestaande literêre en linguistiese model.

Die skynbare teenspraak tussen die tradisionele konsep van vertaalekwivalensie en hierdie beperkte model waarin vertaling gegiet word, kan alleen opgelos word deur te postuleer dat norme van die belangrikste faktore is wat die tipe ekwivalensie en die omvang daarvan bepaal wat deur ' $n$ werklike vertaling geopenbaar word. Die bestudering van riorme verteenwoordig 'n onmisbare stap om vas te stel in hoeverre die gepostuleerde ekwivalensie werklik bereik is.

\section{Van'n vertaling na die toegepaste norme}

\subsection{Die ontleding van die vertaling}

Om uit 'n vertaling af te lei watter tipe ekwivalensie die vertaler nagestreef het en deur watter norme hy hom laat lei het, stel Toury (1985: 19-38) 'n bepaalde prosedure voor. Weens ruimtebeperking is slegs die eerste bladsy van die boek Alice se Avonture in Wonderland ontleed. Hierdie beperking in die omvang van die data het daartoe gelei dat slegs enkele heel voorlopige formulerings aangebied kon word van die preliminere en operasionele norme en ten slotte ook van die inisiële norm wat by die vertaling toegepas is. Daar is nie 'n ontleding gemaak van die globale ekwivalensie wat in die vertaling as geheel tot stand gebring is nie.

Indien voorlopig aanvaar word dat hierdie teks ' $n$ vertaling is, kan by nadere ondersoek vasgestel word of dit wel die geval is. As dit met die bekende Engelse boek "Alice's Advertures in Wonderland" van Lewis Carroll, vergelyk word, word dit duidelik dat André Brink, wat as vertaler genoem word, waarskynlik bogenoemde werk as bronteks gebruik het. Indien aan hierdie Afrikaanse teks dus voorlopig die status van VERONDERSTELDE vertaling toegeken word, het dit as geheel die status van 'n VERTAALVERSKYNSEL en die samestellende dele daarvan die status van VERTAALVERSKYNSELS. Afgesien van sy veronderstelde status as 
vertaling, is hierdie teks ook linguisties, stilisties en inhoudelik as 'n literêre teks binne die doeltaal-polisisteem aanvaarbaar.

Deur dje vertaling met die bronteks te vergelyk moet vervolgens pare vasgestel word wat in elke geval bestaan uit 'n vertaaloplossing uit die doelteks met sy korresponderende vertaalprobleern uit die bronteks. (Sien Bylae no.1.) in beginsel kan enige eenheid op enige tekstueel-linguistiese vlak en met enige trefwydte daarvoor gebruik word. Die probleemgedeelte in die bronteks hoef ook nie identies in rang of trefwydte met die oplossingsgedeelte te wees nie. In die oplossingsgedeelte mag daar net nie oorblyfsels van oplossingsgedeeltes van ander probleemgedeeltes wees as die probleemgedeelte waarmee eersgenoemde oplossing korrespondeer nie.

Omdat hierdie ondersoek daarop gemik is om die funksionele verhoudings wat deur hierdie pare gereflekteer word te beskryf en te verklaar, is dit belangrik dat die vergelyking telkens vanuit die hoek van die doelteks benader moet word. Daar moet gedurig oorweeg word hoe die verhouding tussen elke oplossing en probleem aansluit by die globale doelstellings wat die vertaler voor oë gehad het en die vertaalnorme waaraan hy hom bewustelik of intuitief onderwerp het of waaraan sy opdraggewer hom onderwerp het.

As 'n volgende stap moet 'n swak adekwate vertaling van die bronteks gemaak word aan die hand waarvan die doelteks met die bronteks vergelyk kan word. (Sien Bylae no.2.) Hierdie swak adekwate vertaling is 'n vertaling wat

a) 'n "maksimale rekonstruksie" (Toury 1980: 108) of "getroue weergawe" (Toury 1980: 141), in die doeltaal is, van die tekstuele verhoudings en funksies binne die bronteks asook van die norme wat hulle in die bronteks laat geld, en

b) moet so ver gevoer word as wat die reëls van die doeltaalgrammatika dit toelaat. (Toury 1980: 49, 54, 55, 75, 116-117)

Die swak adekwate vertaling moet as 'n tertium comparationis dien, d.w.s. 'n derde teks wat as onveranderljke maatstaf yir hierdje vergelyking gebruik word. Die doel van hierdie vergelyking is om die afstand (verskil) te bepaal wat bestaan tussen die 
werklike ekwivalensie (ooreenkoms tussen doel- en die bronteks) en die maksimale ekwivalensie (ooreenkoms tussen die adekwate vertaling en die bronteks). Bogenoemde afstand (indien daar ' $n$ afstand of verskil is) tussen die twee vlakke van ekwivalensie verteenwoordíg die verskuiwings wat binne die bepaalde oplossingprobleem-pare plaasgevind het.

Vervolgens moet hierdie verskuiwings noukeurig geïdentifiseer en beskryf word. (Sien par.6.2.) Op grond van die verskuiwings moet veralgemenings gemaak word om die vertaalnorme te identifiseer waarvolgens die doelteks tot stand gekom het. (Sien par.6.2) Die veralgemenings wat hier vereis word, is uitsprake met ongeveer die volgende inhoud:

a) 'n spesifieke soort vertaalkeuse van die vertaler

b) kom herhaaldelik voor

c) in 'n spesifieke soort situasie.

Nadat die geïsoleerde norme vasgestel is, moet daar oorgegaan word tot ' $n$ geïntegreerde globale verhouding tussen die doelteks en die swak adekwate vertaling. Op hierdie manier word die vertaler se werklike benadering tot vertaalekwivalensie vir die bepaalde teks vasgestel. (Sien par.6.3)

\subsection{Preliminêre norme}

Soos bespreek in par. 5.3.1 het die preliminère norme te doen met die spesifieke vertaalbeleid en die direktheid van die vertaling. Op die stofomslag van die boek verklaar die uitgewer dat die Afrikaanse uitgawe van "Alice in Wonderland" vir die eerste keer in 1965 verskyn het om die publikasie van die oorspronklike werk, 100 jaar tevore, te gedenk. Die bronteks is gekies omdat dit beskou word as van die bekendste produkte van die Westerse letterkunde. Tot op daardie stadium was hierdie produkte in Afrikaans of glad nie beskikbaar nie, of in die meeste gevalle net in sterk verkorte of verwerkte vorm waarin te veel van die oorspronklike verlore gegaan het. Met die reeks "Uit die verhaleskat van die Weste" wou die uitgewer in feitlik alle gevalle die volledigste uitgawes publiseer wat tot dusver in Afrikaans verskyn het. Op die titelbladsy word aangedui dat hierdie Afrikaanse vertaling deur André P. Brink gedoen is. 
http://spilplus.journals.ac.za/

6.3

Operasionele norme

\subsubsection{Matriksnorme}

Die belangrikste matriksnorm (sien par.5.3.2.1) waaraan die uitgewer en die vertaler van hierdie Afrikaanse uitgawe hulle onderwerp het, was om die bronteks so volledig moontlik in sy oorspronklike vorm weer te gee. Al die beroemde tekeninge wat John Tenniel vir die oorspronklike teks gemaak het, is gereproduseer. Ook die stofomslagontwerp is op 'n tekening van Tenniel gebaseer.

Wat die verhaal self betref, is die hoofstuk- en paragraafindeling, en die plasing van die rympies en die 42 illustrasies getrou nagevolg. Selfs die sinsindeling korrespondeer in 'n hoë mate met die bronteks.

\subsubsection{Tekstuele norme}

Die tekstuele norme (sien par. 5.3.2.2), wat betrekking het op die werklike verbale formulering van die doelteks, is geïdentifiseer nadat die vertaalverskuiwings geïdentifiseer en beskryf is.

In hierdie paragraaf volg 'n opsomming van die belangrikste verskuiwings wat by die vertaling van die bronteks plaasgevind het. Eers word aangetoon hoeveel keer 'n bepaalde tipe verskuiwing voorgekom het en daarna word 'n kort beskrywing daarvan gegee. Vervolgens word 'n norm geformuleer wat bewustelik of intuitief deur die vertaler toegepas is toe hy die betrokke verskuiwings gemaak het.

By die bestudering van die onderstaande norme is dit belangrik om steeds in gedagte te hou dat hulle van toepassing is op die vertaling van Engelse kinderliteratuur in Afrikaans. Die vertaler het hom gerig op die intelligente, moderne, Afrikaanse kind van ongeveer tien jaar en ouer - alhoewel die bronteks sowel as die vertaling vir volwassenes aangename en vermaaklike leesstof bied. 
(1) Agtien verledetydsvorme van die werkwoord is verander in historiese presens-vorme. (Sien vertaalpaar 1,6,7,9,10,11,12,13, $14,15,19,27,28,29,30,31,35$, еп 37 .)

Vertaalnorm: Verledetydsvorme van die werkwoord word gewoonlik met die historiese presensvorme van die werkwoord vertaal, behalwe in die volgende gevalle: a) voltooid verledetydsvorme, (sien vertaalpaar 5,32) b) terugblikke op gebeure wat verder terug lê as die onmiddellike gebeure van die verhaal, (sien vertaalpaar $22,23,25,26$ ) en c) terloopse kommentaar van die skrywer (sien vertaalpaar 17,18 ).

(2) In sestien gevalle is informele (soms gemoedelike) woorde, frases en morfologiese konstruksies gebruik waar hierdie uitdrukkings of konstruksies nie in die bronteks voorgekom het nie of waar die bronteks neutrale vorme gebruik het. (Sien informele uitdrukkings soos in vertaalpaar 1,4,8,10,33 en 37; verkleiningsuitgange soos in 2,6 en 15; modale bywoorde soos in 24,24 en 27; bywoorde van wyse soos in 1, van plek soos in 2, van tyd soos in 32 en verkorte vorme soos in vertaalpaar 7.)

Vertaalnorm: Oorweeg die gebruik van informele uitdrukkings wat sal pas in die verhaalstyl vir gevorderde kinders, waar sulke informele uitdrukkings of konstruksies in die bronteks ontbreek of neutrale uitdrakkings gebruik word.

(3) In ses gevalle is moeiliker sinskonstruksies vereenvoudig of langer sinne in korter sinne verdeel. (Sien vertaalpaar 3,13,17,22,27,36.)

Vertaainorm: Oorweeg die vereenvoudiging van moeilike sinskonstruksies of die verdeling van lang sinne in korter sinne waar sulke doeltaalsinne ornodig hoë eise aan die gevorderde kind stel of sy begrip van die teks kan belemmer.

(4) In vyf gevalle is "neutrale" uitdrukkings vervang deur doeltaaluitdrukkings wat meer idiomaties gekleur is. (Sien vertaalpaar $8,11,14,21,33$.)

Vertaalnorm: Oorweeg die gebruik van uitdrukkings wat meer idionaties gekleurd is en sal pas in die verhaalstyl vir gevorderde kinders, waar neutrale 
uitdrukkings in die bronteks voorkom of waar bykomende idiomatiese uitdrukkings goed by die doelteks aansluit.

(5) In ses gevalle is minder gebruiklike woorde, uitdrukkings en sinskonstruksies vervang deur gebruikliker vorme, of die uitdrukking is bloot weggelaat. (Sien vertaalpaar 9 (woordorde), 11 en 32 (byvoeging), 12 en 18 (woordkeuse), 17 (weglating).

Vertaalnorm: Oorweeg die vervanging van minder gebruiklike uitdrukkings en sinskonstruksies met gebruikliker uitdrukkings en sinskonstruksies, behalwe in gevalle waar die minder gebruiklike vorme om stilistiese redes voorkeur moet kry.

\subsection{Die Inisiële norm}

Die inisiële norm (sien par. 5.3.3) het betrekking die vertaler se basiese keuse tussen bronteks- of doelteksgerigtheid, of op 'n posisje wat èrens tussen hierdie twee pole lè. Dit wil voorkom of die vertaler met hierdie vertaling 'n middeweg tussen hierdie pole probeer volg het.

Sy doeltaalgerigtheid blyk uit sy poging om die outeur se spitsvondige taal, sy dolrympies, parodieë en woordspelinge in natuurlike, idiomatiese Afrikaans te vertaal omdat ' $n$ letterlike vertaling daarvan die verrassende sin en pragtige teenstellings heeltemal verlore sou laat gaan. Die taalspel sou soveel probleme vir die kinderleser oplewer dat die genot van die werk vir bom verlore sou raak. 'n Bespreking van literêre middele soos spitsvondigheid, teenstellings en taalspel, hoort eintlik tuis by die bespreking van die tekstuele norme, maar die beperkte data het nie genoeg voorbeelde opgelewer vir 'n formele bespreking van die literêre norme nie.

Die vertaler se bronteksgerigtheid blyk uit sy poging om so na as moontlik aan die oorspronklike inhoud en die woordspel te bly. Waar die outeur' $n$ bekende Engelse gedig in 'n nuwe komiese gedaante herskep het, het hy 'n Afrikaanse model gebruik, maar tog 50 ver moontlik die oorspronklike inhoud gebruik. 


\section{http://spilplus.journals.ac.za/}

\section{BYLAE 2}

'n Swak adekwate vertaling ("weak adequate translation") van Alice's Adventures in Wonderland met 'n aanvaarbare vertaling ("acceptable translation"), beide verdeel in tekssegmente vir die identifisering van vertaalverskujwings

\begin{tabular}{|c|c|c|c|}
\hline & Swak Adekwate Vertaling & & Aanvaarbare Vertaling \\
\hline 1. & Alice het baie moeg begin word & 1. & $\begin{array}{l}\text { Alice begin stadigaan baie } \\
\text { moeg raak }\end{array}$ \\
\hline 2. & $\begin{array}{l}\text { orn by haar suster op die } \\
\text { rivieroewer te sit, }\end{array}$ & 2. & $\begin{array}{l}\text { on daar langs haar sussie } \\
\text { op die bank te sit }\end{array}$ \\
\hline 3. & $\begin{array}{l}\text { en om niks te he om te doen } \\
\text { nie: }\end{array}$ & 3. & en niksdoen: \\
\hline 4. & een of twee keer & 4. & 'n slag of wat \\
\hline & het sy al in die boek geloer & 5. & $\begin{array}{l}\text { het sy al geloer na die } \\
\text { boek }\end{array}$ \\
\hline & $\begin{array}{l}\text { wat haar suster besig was om } \\
\text { te lees }\end{array}$ & 6. & wat haar sussie sit en lees, \\
\hline 7. & $\begin{array}{l}\text { maar dit het geen prente of } \\
\text { gesprekke daarin gehad nie, }\end{array}$ & 7. & $\begin{array}{l}\text { maar daar is g'n prente of } \\
\text { gesprekke in nie, }\end{array}$ \\
\hline & $\begin{array}{l}\text { "en wat is die nut van 'n } \\
\text { boek", }\end{array}$ & 8. & $\begin{array}{l}\text { "en wat is daar nou in's } \\
\text { boek }\end{array}$ \\
\hline
\end{tabular}

\begin{tabular}{|c|c|c|}
\hline $\begin{array}{l}\text { 9. dink Alice, "sonder prente of } \\
\text { gesprekke?" }\end{array}$ & 9. & $\begin{array}{l}\text { sonder prente of } \\
\text { gesprekke?" dink Alice. }\end{array}$ \\
\hline $\begin{array}{l}\text { 10. Daarom was sy besig om dit } \\
\text { in haar eie gedagtes te } \\
\text { oorweeg, }\end{array}$ & 10. & $\begin{array}{l}\text { Daarom sit sy stilweg en } \\
\text { wonder }\end{array}$ \\
\hline 11. (so goed as sy kon, & 11. & (so goed as wat sy kan, \\
\hline $\begin{array}{l}\text { 12. want die warm dag het haar } \\
\text { baie slaperig en dom laat } \\
\text { voel), }\end{array}$ & 11. & $\begin{array}{l}\text { want die warm dag laat } \\
\text { haar vaak en dom voel) }\end{array}$ \\
\hline $\begin{array}{l}\text { 13. of die plesier om 'n made- } \\
\text { liefieketting te maak dit } \\
\text { die moeite werd sou maak om } \\
\text { op te staan en madeliefies } \\
\text { te pluk, }\end{array}$ & & $\begin{array}{l}\text { of dit die moeite werd sal } \\
\text { wees om op te staan en te } \\
\text { gaan gousblommetjies pluk } \\
\text { om 'n blomketting te maak; }\end{array}$ \\
\hline
\end{tabular}




\begin{tabular}{|c|c|c|}
\hline Swak Adekwate Vertaling & & Aanvaarbare Vertaling \\
\hline 14. $\ldots . .$. & 14. & en sy sit nog so \\
\hline $\begin{array}{l}\text { 15. toe 'n Wit Konyn met pienk } \\
\text { oë skielik }\end{array}$ & 15. & $\begin{array}{l}\text { toe kom daar skielik 'n } \\
\text { Wit Konyn met pienk ogies }\end{array}$ \\
\hline 16. naby haar verby gehardloop het. & 16. & vlak by haar verbygehardloop. \\
\hline
\end{tabular}

\begin{tabular}{|c|c|}
\hline $\begin{array}{l}\text { 17. Daar was niks wat so baie } \\
\text { merkwaardig daaraan was nie; }\end{array}$ & $\begin{array}{l}\text { 17. Daar was niks besonders } \\
\text { daaromtrent nie; }\end{array}$ \\
\hline $\begin{array}{l}\text { 18. ook het Alice nie gedink dat } \\
\text { dit so vreeslik baie seldsaam } \\
\text { is }\end{array}$ & $\begin{array}{l}\text { 18. en daarom het Alice ook } \\
\text { glad nie gedink dis jets } \\
\text { so besonder ongewoons nie }\end{array}$ \\
\hline $\begin{array}{l}\text { 19. om die Konyn vir homself te } \\
\text { hoor sé: }\end{array}$ & $\begin{array}{l}\text { 19. toe sy die Konyn vir } \\
\text { homself hoor se: }\end{array}$ \\
\hline 20. "O aarde! $O$ aarde! & 20. "O my aarde, o my aardel \\
\hline 21. Ek sal te laat wees!" & 21. Ek gaan laat wees!" \\
\hline
\end{tabular}

\begin{tabular}{|l}
\hline $\begin{array}{l}\text { 22. (toe sy agterna daaroor gedink } \\
\text { het, }\end{array}$ \\
\hline $\begin{array}{l}\text { 23. het dit by haar opgekom } \\
\text { dat sy hieroor behoort te } \\
\text { gewder het, }\end{array}$ \\
\hline
\end{tabular}

25. maar destyds

26. het dit alles heel natuurlik gelyk);

27. maar, toe die Konyn werklik
'n horlosie uit sy binne-
baadjiesak gehaal het,

29. en toe voortgehaas het,

30. het Alice op haar voete gespring,

31. want dit het deur harar brein geflits
22. (Toe sy later weer daaraan terug gedink bet

23. het sy besef

24. dat sy dalk tog verwonderd moes gewees het daaroor,

25. maar terwyl dit aan die gebeur was,

26. het dit alles doodnatuurlik voorgekom.)

27. Maar toe die Konyn nou so waat ' $n$ horlosie uit sy onderbaadjiesak haal,

28. en daarna kyk

29. en hom toe weer verder haas,

30. toe spring Alice op haar voete,

31. want sy besef 


\begin{tabular}{|c|c|c|}
\hline Swak Adekwate Vertaling & & Aanvaarbare Vertaling \\
\hline $\begin{array}{l}\text { 32. dat sy nooit voorheen 'n } \\
\text { konyn gesien het of met } \\
\text { 'n onderbaadjiesak }\end{array}$ & 32. & $\begin{array}{l}\text { dat sy nog nooit vantevore } \\
\text { 'n konyn met 'n onder- } \\
\text { baadjiesak gesien het nie, }\end{array}$ \\
\hline $\begin{array}{l}\text { 33. of thet 'n horlosie om daar- } \\
\text { uit te haal nie, }\end{array}$ & 33. & $\begin{array}{l}\text { wat nog te sè van 'n } \\
\text { horlosie wat hy daanuit } \\
\text { kan haal; }\end{array}$ \\
\hline 34. en brandend van nuuskierigheid, & 34. & $\begin{array}{l}\text { en brandend van } \\
\text { nuuskierigheid }\end{array}$ \\
\hline $\begin{array}{l}\text { 35. het sy oor die veld agter hom } \\
\text { aangehardloop, }\end{array}$ & 35. & $\begin{array}{l}\text { hardloop sy agterna oor } \\
\text { die veld, }\end{array}$ \\
\hline 36. en was net betyds om te sien & 36. & net betyds orn te sien \\
\hline $\begin{array}{l}\text { 37. hoe hy in 'n groot konyngat } \\
\text { onder die heining afspring. }\end{array}$ & 37. & $\begin{array}{l}\text { hoe hy in 'n groot } \\
\text { konyngat onder die heining } \\
\text { inwoerts. }\end{array}$ \\
\hline
\end{tabular}

